Meta

Journal des traducteurs

Translators' Journal

\title{
SVO Word Order Errors in English-Arabic Translation
}

\section{Reima Sado Al-Jarf}

Volume 52, numéro 2, juin 2007

URI : https://id.erudit.org/iderudit/016072ar

DOI : https://doi.org/10.7202/016072ar

Aller au sommaire du numéro

Éditeur(s)

Les Presses de l'Université de Montréal

ISSN

0026-0452 (imprimé)

1492-1421 (numérique)

Découvrir la revue

Citer cet article

Sado Al-Jarf, R. (2007). SVO Word Order Errors in English-Arabic Translation. Meta, 52(2), 299-308. https://doi.org/10.7202/016072ar

\section{Résumé de l'article}

Nous avons assemblé un corpus d'erreurs de structure SVO tirées de projets d'étudiantes en traduction. Les structures déviantes sont jugées selon des critères syntaxiques, sémantiques, pragmatiques et de discours. Nous présenterons le pourcentage des erreurs intra- et interlinguales, les contextes syntaxiques où les sujets sont mal placés, les stratégies employées pour imposer l'ordre SVO, et les cas de connaissance insuffisante de la première langue. Nous donnerons des suggestions pour améliorer chez les étudiants la perception des contraintes pragmatiques, syntaxiques et de discours dans la traduction des structures SVO.
Ce document est protégé par la loi sur le droit d'auteur. L'utilisation des services d'Érudit (y compris la reproduction) est assujettie à sa politique d'utilisation que vous pouvez consulter en ligne.

https://apropos.erudit.org/fr/usagers/politique-dutilisation/ 


\title{
SVO Word Order Errors in English-Arabic Translation
}

\author{
REIMA SADO AL-JARF \\ King Saud University, Riyadh, Saudi Arabia \\ reima2000_sa@yahoo.com
}

\begin{abstract}
RÉSUMÉ
Nous avons assemblé un corpus d'erreurs de structure SVO tirées de projets d'étudiantes en traduction. Les structures déviantes sont jugées selon des critères syntaxiques, sémantiques, pragmatiques et de discours. Nous présenterons le pourcentage des erreurs intra- et interlinguales, les contextes syntaxiques où les sujets sont mal placés, les stratégies employées pour imposer l'ordre SVO, et les cas de connaissance insuffisante de la première langue. Nous donnerons des suggestions pour améliorer chez les étudiants la perception des contraintes pragmatiques, syntaxiques et de discours dans la traduction des structures SVO.
\end{abstract}

\section{ABSTRACT}

An error corpus of deviant SVO structure was collected from the translation projects of students majoring in translation. Syntactic, semantic, pragmatic and discoursal criteria were used to judge the deviations. Percentages of interlingual and intralingual errors, the syntactic contexts in which subjects were misplaced, the strategies used to impose SVO order, and areas of $\mathrm{L} 1$ inadequate competence will be reported. Implications for increasing students' awareness of the pragmatic, discoursal and syntactic constraints in translating SVO structures will be provided.

\section{MOTS-CLÉS/KEYWORDS}

deviant structure, pragmatics, SVO word order, syntactic constraints, translation error analysis

\section{Introduction}

Errors are an indispensable part of learning translation. They result from two psychological processes: transfer and simplification (Arabski 1979). Numerous researchers have examined the lexical, structural, semantic, pragmatic, and stylistic errors in translation. For instance, Snock, (1990), Jordens (1990), Verrips and Weissenborn (1992), Kirby (1988), Mavrides (1990), Ross (1987), Wongspthorn (1983), He (1996), and Dancette (1993) investigated word order errors in English, German, Spanish, French, Dutch, Thai and Chinese. They examined the acquisition of verb placement, passives and preposition in L2 and translation. Khafaji (1996), Farghal and AlShorafat (1996) and Goldman (1989) reported errors in passive structures and prepositions in Arabic. Although word order has been found to constitute a major difficulty in translation, studies that analyze subject-verb-object (SVO) errors and verb-subject-object (VSO) errors in English-Arabic translation are lacking.

This study attempted to describe the nature, frequency and possible sources of deviant subject-verb-object structures in the translation of texts from English into Standard Arabic by advance college students majoring in translation. Specifically, the 
present study aimed to find out the percentage of deviant SVO sentences in EnglishArabic (L2/L1) translation, the number of deviations in misplaced verbs, the percentage of interlingual errors and intralingual errors and areas of inadequate L1 competence. In addition, this study reported the percentage of pragmatically, discoursally and semantically deviant SVO structures, examined the syntactic environments in which deviant SVO structures occurred and the strategies student translators used to impose an SVO word order.

Examination of SVO word order errors is intended to reveal students' weaknesses, the processes they employ in translating VSO sentences, and the factors that influence their language-switching behavior and thinking processes. It will shed some light on their awareness of word order differences between English and Arabic. Awareness of the deviant paths of translation may disclose neglected areas of translation teaching and theory and will be helpful in planning translation instruction.

\section{SVO and VSO in Arabic}

According to traditional Arab grammarians, VSO (Verbal sentences) is the normal syntactic word order. According to generative grammar, VSO is the basic word order and SVO is derived through subject movement. VSO order is unmarked for focus, emphasis and information distribution. Statistically, VSO order is more frequent than SVO. Al-Khuli (1982) collected a sample of eighty 50-word long paragraphs covering literature, sociology, education, history, religion, literary history, geography, economics, physics, health, mathematics, psychology, biology, general science from monthly and weekly magazines, daily newspapers, and junior and senior high school books. He found that verbal sentences constitute 64.21\%. In addition, Abdul-Raof (1998) and Parkinson (1981) found variations in the percentage of VSO within particular genres and styles. The percentage of VSO structures in novels and plays was found to be $60 \%-87 \%$, in main headlines (100\%), in main and sub-headlines $(92 \%)$, in political speeches (48\%), in editorials and short stories (39\%), in linguistics dissertations $(34 \%)$, in magazines (30\%), in scholarly journals \& political science $(27 \%)$, and in news articles $(8 \%)$. Furthermore, Parkinson found variations in the use of VSO pattern by Arab writers: Mohammed Abdo (90\%), Ahmed Amin (87\%), Taha Hussein (87\%), and Shibly Shumayyil (54\%).

According to Abdul-Raof (1998), Arabic speakers/writers prefer VSO unless there is a good reason to use SVO. The shift from VSO to SVO is pragmatically motivated, and is related to discourse and sometimes style. Pragmatic and discoursal factors that affect the use of the SVO order include implied contrast and new information, introducing a discourse topic, discourse structure and organization of information.

As to the semantic functions of VSO and SVO in SA, the SVO pattern gives emphasis to the subject, whereas the VSO pattern gives emphasis to the verb. There is a strong tendency for given topical information to be followed by new asserted information. The natural tendency to topicalize the subject and to place topical or given information in sentence-initial position accounts for the frequency of subject initial word-order types (Abdul-Raof). The various meanings in sentences are identified by the communicative intention of the speech act, the speaker's emotional state, and the theme-rheme composition (rheme is the part of an utterance that contains the aim of the message and the theme is the part that carries additional information). 
Syntactically speaking, SVO structures (nominal sentences and clauses) are used in the following cases: (i) sentences consisting of a subject and a predicate; (ii) sentences beginning with emphatic /?inna/; (iii) sentences beginning with auxiliary / kaana/; (iv) sentences beginning with the negative particle /laa/; (v) after /THanna/ 'thought' group; (vi) after /qaala/ 'said'; (vii) after /?axbara/ 'told' and /?araa/ 'showed,' (viii) in answer to certain interrogatives. On the other hand, VSO structures (verbal sentences) are used in the following cases: (a) Conditional sentences beginning with certain particles; (b) When independent subject pronouns are deleted. Independent pronoun usage in subject position is discourse-based; (c) After sentence initial adverbials and prepositional phrases, (d) in passive clauses (Sharif 1993; Al-Khuli 1982).

Disjuncts and conjuncts, coordinating and subordinating conjunctions and adverbials that occur initially do not affect the VSO order. NP's which are most thematic due to their information status occupy the thematic position. The information status of an NP comes either from the inherent saliency or from its discourse acquired prominence. The discourse focus = paragraph topic. Extraposed subject. Extraposed theme. Contextual constraints (genre) influence the subject/agent distribution. Word order is controlled by pragmatic considerations. It is the discourse-neutral order. Quoting clauses always start with a verb. Subject, theme and agent tend to coincide in narrative discourse, personal commentary and cleft sentences but do not tend to coincide in expository, descriptive or instructional discourse. Discourse-pragmatic factors are the major driving force for the shift from one word order to another.

To conclude, English is an SVO language but Arabic displays a greater variety of choices than English. The subject-verb pattern in SA is a free variant of regular patterns, while in English it is a restricted variant. The choice between VSO and SVO in Arabic is related to syntactic, pragmatic, discoursal and semantic factors available in a particular context.

\section{Subjects}

46 senior female students majoring in translation at the College of Languages and Translation (COLT), King Saud University, Riyadh, Saudi Arabia participated in the study. All the subjects were native speakers of Arabic. They all had completed courses in EFL (66 hours), linguistics (11 hours), interpreting (15 hours), written translation in 18 subject areas (36 hours), target culture (7 hours), and Arabic syntax and morphology (18 hours).

\section{Data Collection and Analysis}

Since it is difficult to calculate the percentage of deviant SVO structures in an output translation, 32 senior students took a test in which they translated ten English stretches of discourse into Arabic (median length $=20$ words; range $=8$ - 37 words), to find out the percentage of deviant SVO in student translation.

In addition, 472 deviant SVO structures were collected from the translation projects of 14 graduating seniors. Errors were collected from the first translation of the source text. Deviant SVO sentences were defined as those clauses or sentences in which the verb was misplaced after the subject. They were judged to be deviant in relation to the context in which they occurred. Judgments of deviation were based on 
syntactic, pragmatic, discoursal, and semantic criteria. Deviant SVO sentences were submitted to a panel of 3 professors of Arabic to verify the error data.

Corpus analysis started by highlighting the verb and subjects which were misplaced before the verbs, identifying the particles that preceded the subjects, the syntactic violations contained within each verb, and the type of sentence in which deviations occurred. Each error was then classified as being interlingual, due to transfer from English, or intralingual, due to inadequate competence in Arabic. Intralingual errors covered instances where the students failed to identify the syntactic, pragmatic, discoursal and semantic conditions that require an SVO structure. Pragmatic, discoursal and semantic errors are those where the SVO order was not motivated by implied contrast, introduction of a topic of discourse, organization of information, genre, focus and theme. SVO sentences that are semantically deviant are those where the communicative intention of the speech act, the speaker's emotional state, and the theme-rheme composition do not require an SVO order. Syntactic errors are those in which a grammatical rule is violated. The syntactic contexts (environments) in which the verb was misplaced after the subject included the type of sentence where the deviations occurred (Simple, Compound, Complex), the distance between subject and verb, the complexity of the NP containing the subject, the particles preceding the subject and verb, types of conjunctions used, the type of verb used (be or main verb), voice of verb.

Avoidance strategies refer to those structures used to place the subject before the verb instead of using a VSO structure. Those strategies included types of particles used, verb deletion, use of derived verbal noun, adding the subject pronoun /huwa/ 'he.' Performance errors due to memory limitations, fatigue and the like, were excluded. Percentages of errors in each category and inter-analyst reliability were calculated.

\section{Results and discussion}

\subsection{Frequency and Source of SVO Errors}

The English-Arabic translation test results showed that student translators have rendered 176 or $55 \%$ SVO sentences in which the subject was misplaced before the verb, although all the English stretches of discourse on the test required an Arabic translation with a VSO order. In addition, examination of the 472 deviant SVO structures in Arabic collected from the translation projects showed that the students calqued the English SVO order. These finding are supported by previous translation research. For example, Wilss (1974) found that interference occurs from L2 to L1 as illustrated by German students learning English. In translating literary works from English into Chinese and from Chinese into English indicated that translators used the same word order, sentence order and structure as the original (He 1996). They transferred L2 word order and structures into L1 translations. Moreover, Farghal (1996), Farghal and Al-Shorafat (1996) found that Arab student translators tended to translate English passives into Arabic passives. They used strategies that sought structural equivalence between English and Arabic. In translating German structures containing prepositions into Arabic, interference was found to be a major cause of errors (Goldmann 1989).

One explanation for transferring the English SVO word order to Arabic is the students' inability to account for word order differences between both languages. In 
English-Arabic translation, students need to develop an awareness of the relationship between word order and thematic structure and must recognize the types of phrases that require use of an SVO construction. Olohan and Zahner (1996) asserted that translation students who are aware that languages differ conceptually are better prepared to recognize differences and provide more accurate translations. Failure to account for the structural differences between Dutch (a V-oriented language) and Italian (an N-oriented language) was found to be a major source of errors made by Dutch-Italian translators (Ross 1987).

A second explanation is the students' tendency to translate word-by-word rather than by meaning. They seemed to translate imitatively rather than discriminately. Lado (1983) noted that unskilled translators operate largely at the level of individual words and phrases, whereas skilled translators go from one language into the deep memory /thought level and then back into the second language. This is also consistent with findings of studies on other languages. Thai students translated descriptive, explanatory and persuasive texts from Thai (L1) into English (L2). Weaknesses in Thai-English translations revealed a tendency to translate word-by-word rather than by meaning (Wongsothorn 1983). When confronted with an English passive construction, Arab translators either used a corresponding Arabic active or translated the sentence word for word (Khafaji 1996).

A third explanation is lack of comprehension of the source text due to its linguistic complexity and inability to reproduce the meaning in the target language. Dancette (1993) found that lack of comprehension underlies most errors in the translation of informative, argumentative and rhetorical texts by M.A. Canadian students. Rodriguez (1996) attributed the orthographic, syntactic, morphological, semantic and stylistic errors in translating medially complex pragmatic texts from English into Spanish to insufficient comprehension of the original text and poor development of abilities in the native language. In this study, the students had difficulty processing embedded sentences, identifying reduced relative clauses, locating the target verb and connecting it with the controlling subject. In example (1), the target verb 'is' was deleted and the passive verbs 'is accumulated' and 'sealed' were replaced by the derived nouns /taraakumi/ and /lmasduuda/. The subordinate clauses 2, 3, 4 were reduced to one clause. In the translation, /yu9rafu bismi maSyada/ 'known as a trap' refers to 'a geological formation' although in English it does not. Interestingly, the passive verb /yu9rafu/ took a mid-sentence position as the verb 'known' in the original. In (2), the students did not seem to understand the meaning of 'is caught between fellow' and 'chief customer U.S.,' therefore, both phrases were deleted. The rest of the sentence was translated word for word.

(1) A geological formation [in which oil is accumulated]1 [is a permeable reservoir of rock] 2 [sealed by a cap rock]3 [known as a "trap"]4 and is capable of exploitation as an oil field.

wa-ttakwiinu l-jiyuuluujii [min Haythu tarakumi SSuxuuri l-xaazina l-masduuda fii Saxri l-GiTaa?] yu9rafu bi-smi maSyada .....

(2) Venezuela, world's No. 1 crude exporter, [is caught between fellow] OPEC members and [chief customer U.S.] during oil crisis spawned by Arab-Israeli war.

vinizwillaa lmuSaddiru l?awwal li-nnafTi l-xaam wa-hiya ?aHadu ?a9Daa?i munaDHDHamati upik xilaala ?azmati nnafTi nnaashi?a bi-sababi 1-Harbi 1-?arabiyya l-?israa?iiliyya. 
A fourth explanation is inadequate competence in Arabic. In 32\% of the deviant SVO structures, at least one Arabic grammatical rule was violated, $62 \%$ were pragmatic and 55\% were discoursal due to inability to recognize the discourse structure and information organization as illustrated in the examples below.

\subsection{Syntactic Contexts in Which Deviant SVO's Occurred}

It was found that $34 \%$ of the subjects were misplaced before the verb when the head noun was embedded in a long or complex NP. For example, in (1) above, the head noun 'geological formation' is embedded in a long and complex NP and is separated from the target verb 'is' by a relative clause. $8 \%$ of the misplaced subjects were separated from the controlling verbs by a relative clause. In (3) below, the head noun 'This' is separated from the target verb 'proved' by a long and complex conjoined NP. In (4) the head noun 'relationship' is also embedded in a long NP. In (1), (3) and (4) the target verbs have a mid-sentence position and follow their controlling head nouns and so do their Arabic equivalents.

(3) This, plus the heroic stand of the Belgians and the stubborn resistance of the French and British, proved to be Germany's...

wa-haadha ttaSarruf, bi-l-?iDaafati?ila l-wiqfa l-butuuliyya lil-baljiik wa-lmuqaawama 1-9aniida min0, qibali faransaa wa-biriTaanyaa kaana ssabab fii haziimati ?almaanya...

(4) The relationships between local administrative units and other agencies of local government vary widely from state to state.

wa-l-9alaaqa bayna l-wiHdaati l-?idaariyya fi-l madaarisi l-maHaliyya wa-l-wakaalaati l-?uxraa li-l-Hukuuma l-maHaliyya taxtalifu kathiiran min wilaaya li-?uxra

In $17 \%$ of the deviant SVO structures, subjects were misplaced before passive verbs even when the subjects are short NP's. In (5), 'was produced' was replaced by the Arabic passive verb/?untija/. The subject /zzayti lxaam/ 'crude oil' is a short NP, however it was misplaced before the verb. /fa/, a topicalizer, is usually attached to subjects in SVO orders, was added. Here, the students sought structural equivalence between English and Arabic regardless of the differences in passive usage.

(5) Crude oil was produced in quantities in excess of demand, accompanied by a sharp price decrease

fa-zzayti l-xaam ?untija fii muqaaTa9aatin ta-tazaayadu fiiha Ttalab 9alay-hi ma9a nuqSaani ssi9ri l-Haadd.

Moreover, $12 \%$ of the subjects occurring in compound and complex sentences were misplaced before the verb. The Arabic translation of the complex sentence in (6) requires two clauses with a VSO structure. However, in translating the main clause ' $a$ vertical separation occurs,' the students calqued the English SV structure. They violated a rule that requires use of two verbal clauses when using /9indama/, i.e., two clauses with a parallel structure. Another example of lack of parallelism in coordinated clauses is sentence (7). Here, each Arabic clause begins with a conjunction. An Arabic rule that requires use of verbal clauses after conjunctions is again violated. 'Haythu ?inn' /as/ that is followed by an SVO structure was used, although another variant / Haythu/ is followed by a VSO structure beginning with /kaana-t-aa/ 'was + FEM + DUAL' should have been used. In (7), a second rule that requires use of auxiliary verbs 
like /kaana/ and /?aSbaHa/ in sentence initial position was violated. $11 \%$ of the misplaced subjects were misplaced before auxiliary verbs.

(6) As the mixture of gas, oil and water collects under the cap rock, a vertical separation occurs...

wa-9indama ya-tajamma9u xaliiTu l-ghaazi wa-l-maa? wa-nnafT taHta Saxri ssaqf, fa-?inna nfiSaal 9amuudi ya-Hduth.

(7) Bulgaria and Turkey were almost defeated, and Austria was weakening rapidly. (New para).

Haythu ?inna bulghaarya wa-turkiyaa kaan-at-aa1 9alaa washaki l-haziima, baynamaa kaan-at2 nnamsaa ta-D9ufu bi-sur9a.

Furthermore, $3 \%$ of the subjects were misplaced in conditional sentences. In (8) below, the conditional particle /?ithaa/ 'if' was misplaced after the subject /wa ?ay mina lmaa? ?awi zzayt/ any water, oil or gas.' Here a grammatical rule was violated. Like the topicalizer /fa/ in (5) above, /wa/ that is usually attached to subjects in SVO structures was added.

(8) Any water, oil or gas that does not find a sealing cap rock, escapes to the surface, leaving behind an asphaltic deposit.

wa-?ay mina l-maa? ?awi l-Gaazi ?awi zzayt ?ithaa lam yajid Saxru ssaqfi llathii yaquumu bi-saddihi, ya-nfathu ?ilaa ssaTHi...

Also, $6 \%$ of the subjects were misplaced in nominal clauses following /?anna/ or /?an/ 'that' in (9) below, /?anna/ should be followed by a VSO structure and the future particle /sawfa/ should be added to the verb in the main clause. Here again, the students imitated the English source text and sought equivalent SVO clauses.

(9) Vast immigrations... decreased the likelihood that a child educated in a given community would spend the productive years of his life there.

wa-qad qallalati l-hijraatu ....mina Htimaali ?anna TTifla llathii talaqqaa ta9liimahu fii mujtama9in mu9ayyan sawfa yaqDii ...

Finally, although sentences that follow the particle /laakinna/ 'but' or 'whereas' usually have an SVO order, the Arabic sentence in (10) should have a VSO after the particle /laakin/ 'but.' In (10), a rule was violated as the students equated the particles /laakin/ and /laakinna/ and hence sought an equivalent SVO structure as the source text. The emphatic particle /qad/ was added before the verb to make the SVO sentence acceptable.

(10) But, some people might get the infection twice. wa-laakin ba9Da l-?ashxaaS qad yuSaabuun marratayn

\subsection{Avoidance Strategies Used in Connected Discourse and in Isolation}

To impose an SOV order, contrast particles like /?ammaa/ 'as for' that require an SVO order were added in sentence initial position. This strategy was used in $46 \%$ of the deviant SVO structures. In (11), the verb /qaawamuu/ 'fought' was misplaced after the subject /lbaljiikiyyuun/ 'Belgians.' To ensure that the Arabic SVO sentence is acceptable, the emphatic particles /qad/ was added before the verb /qaawamuu/. The particle /?ammaa/ shows contrast and /qad/ shows emphasis. Here again the students sought word order equivalence between English and Arabic regardless of the pragmatic and discoursal intents of the source text. They ignored the way information is 
organized in the source text. This sentence is the first sentence of the paragraph. It is a declarative sentence with a neutral tone, with no emphasis or contrast. Contrast and emphasis are not required by the discourse structure of the original.

(11) The Belgians fought so stubbornly that the Germans were held up at Liege ?ammaa lbaljiikiyyuun fa-qad qaawamuu bi-basaala li-daraja ?anna 1-?almaan tawaqqafuu...

A second strategy was use of the emphatic particle /?inna/ which occurred in $16 \%$ of the deviant SVO structures. In (12), the verb /bada?a/ 'began' was misplaced in sentence mid-position, as it is in the original. The emphatic particle /?inna/ which is used in nominal sentences was added, although the original sentence is the first sentence of the paragraph and is unmarked for emphasis by the discourse structure. In (13) however, the English word order was calqued. The topicalizer /fa/ and emphatic /?inna/ were inserted to ensure an SVO order, although grammatical rules require that a VSO structure follow a PP in sentence-initial position and passive verbs be placed in sentence initial position. Similarly, /?inna/ was added in (6) above, although the English sentence is unmarked for emphasis. In both sentences, the students violated pragmatic and discoursal conditions and violated a syntactic rule that requires use of a verbal main clause in complex sentences beginning with /9indama/.

(12) The commercial production of petrochemicals began in the 1920's. ?inna l-?intaaja ttijaarii mina l-bitruukiimaawiyyaat bada? a fil-9ishriinaat.

(13) In addition to those shapes, Arabic calligraphy was considered a type of Arabesque. wa-bi-l-?iDaafa ?ilaa tilka l-?shkaal, fa-?inna l-Huruufa l-?arabiyya 9tubirat juz?an mina zzaxrafati l-?islaamiyya.

A third avoidance strategy was use of verbal nouns instead of verbs in $16 \%$ of the deviant SVO structures on the test. In (14) the verb 'threatened' was substituted by the verbal noun /tahdiidu/ 'threat' and placed in sentence initial position. The structure of the whole sentence was slightly manipulated to provide for the SVO order. In $8 \%$ of the SVO errors on the test, the lexical verb was deleted as in (2) above.

(14) Iraq threatened to quit OPEC... tahdiidu l-9iraaq bi-qaT9i 9uDwiyyati-haa fii munaDHDHamati upik...

Another avoidance strategy was use of independent subject pronouns in 6\% of the deviant SVO structures. In Arabic, a clitic pronoun is an inherent part of each verb and use of independent subject pronouns is redundant and is discourse based. In (15), the original sentence is declarative, yet the students imitated the original and added the pronoun /huwa/ 'it.' The particle / wa/ was also attached to the subject.

(15) It has 874 members.

wa-huwa yaDummu $8749 \mathrm{uDwan}$.

To summarize, the syntactic contexts in which the deviant SVO structures occurred and the strategies used to impose SVO structures showed that the subjects lack mastery of the following grammatical rules: placing the controlling subject before the verb when it is embedded in a long or complex NP's, when the verb is passive, when conjunctions are used, before auxiliary verbs, when relative pronouns were used, after /?anna/ 'that,' in parallel structures, in conditional sentences, in declarative sentences that require deletion of independent subject pronouns. Those reflect students' 
unawareness of the pragmatic and discoursal constraints imposed on choice of SVO structure. The problem is compounded when the source text requires several layers of analysis.

\section{Conclusion}

The present study attempted to examine the nature of transfer of SVO word order from English (L2) into Arabic (L1). Results revealed students' inability to recognize the differences between English and Arabic word orders; their inability to examine the syntactic contexts and the pragmatic, semantic and discoursal conditions under which SVO sentences are used.

Mastery of SVO and VSO structures in English-Arabic translation can be achieved by improving translation instruction. Special Arabic language courses for translation purposes should be offered. Those should focus on structures in which the subjects were misplaced such as subject embedded in long and complex NP's, with auxiliaries and passives, after conditional particles, after topicalizers, after /laakin/, faulty use of independent subject pronouns, in compound and complex sentences, in clauses requiring a parallel structure, after initial PP. A constant attempt to contrast related areas of English and Arabic word orders should be made. Exercises and tests should require students to recognize examples of VSO and SVO orders in translation situations using texts with different registers and genres. Published translated material and samples of student translations can be used to help students identify deviant SVO structures and analyze SVO determining forces. While reformulating the target text, they should pay attention to the syntactic shifts, particles used, discourse structure, discourse topic, new and given information in the text.

Comparisons of the frequency, sources and causes of deviant SVO structures by beginning and advance translation students need to be investigated by future translation research. Analysis of SVO and VSO errors in the translation of Arabic texts into English is still subject to further investigation.

\section{NOTE}

In the transcription of Arabic words, th = voiceless dento-alveolar fricative; $\mathrm{dh}=$ voiced dento-alveolar fricative; $\mathrm{S}=$ voiceless palato-alveolar sulcal fricative; $\mathrm{H}=$ voiceless pharyngeal fricative; $\mathrm{D}=$ voiced dentoalveolar emphatic plosive; $\mathrm{T}$ = voiceless dento-alveolar emphatic plosive; $\mathrm{S}=$ voiceless dento-alveolar sulcal emphatic fricative; $\mathrm{DH}=$ voiced dento-alveolar sulcal emphatic fricative; $\mathrm{G}=$ voiced uvular fricative; $\mathrm{x}=$ voiceless uvular fricative.

\section{REFERENCES}

Abdul-Raof, H. (1998): Subject, Theme and Agent in Modern Standard Arabic, Surrey, Curzon Press.

Al-Khuli, M. (1982): Al-Taraakeeb al-ahaa?i9a fi llugha al-Arabiyya (Common Structures in Arabic), Dar Al-Uloom Publishing Co.

Arabski, J. (1979): “Contrastive Studies and Interlanguage," Papers and Studies in Contrastive Linguistics 10, pp. 135-143.

Dancette, J. (1993): “The Evaluation of Translation Performance: The weight of comprehension," Turjuman 2-1, pp. 45-61.

Farghal, M. and M. Al-Shorafa (1996): "The Translation of English Passives into Arabic: An empirical perspective," Target 8-1, pp. 97-118. 
Goldmann, I. (1989): "Interference-conditioned Errors in Arabic Instruction: Presented on a corpus of translations of the German prepositions into Arabic," Linguistische Studien 189, pp. 141-151.

He, W. (1996): “The Style of Literary Works in Translation," Perspectives: Studies in Translatology 1, pp. 137-144.

KhafajI, R. (1996): "Arabic Translation Alternatives for the Passive in English," Papers and Studies in Contrastive Linguistics 31, pp. 19-37.

Kirby, J. (1988): "English Verbal Complements. Dutch-speaking Learners and the Role of Length: An Investigation of Error in One Area of English Grammar," Papers and Studies in Contrastive Linguistics 23, pp. 107-118.

Mavrides, V. (1990): An Analysis of Errors Committed by Greek Learners of English in Prepositions, ERIC Document Reproduction Service No. ED 326054.

Olohan, M. and C. Zahner (1996): "Translation Theory and Cognitive Linguistics," in Hickey, T. and J. Williams (eds.), Language, Education and Society in a Changing World, Clevedon, England, Multilingual Matters Ltd.

Parkinson, D. (1981): "VSO to SVO in Modern Standard Arabic: A study in diglossia syntax," Al-Arabiyya 14, pp. 24-37.

Rodriguez, J. (1996): “Analysis of Translation Mistake,” Van Taal tot Taal 40-3, pp. 115-127.

Ross, D. (1987): "Nominal versus Verbal Style (Some Cases of Syntactic Interference in DutchItalian-Dutch Translation," Linguistica Antverpiensia 21, pp. 101-125.

Sharif, M. (1993): Al-Tarakeeb al-naHwiyya (Grammatical Structures), Al-Shabaab Bookstore Publishing.

Snock, G. (1990): "Acquisition of Finite Verb Postposal in Dutch in Different Linguistic Contexts," Université Libre de Bruxelles, Rapport d'activités de l'institut de phonétique 26, pp. 33-58.

Verrips, M. and J. Weissenborn (1992): "Routes to Verb Placement in Early German and French: The independence of finiteness and agreement," in Meisel, J. (ed.) The Acquisition of verb Placement: Functional categories and V2 phenomena in language acquisition, The Netherlands, Kluwer Academic Publishers.

Wilss, W. (1974): Problems in Error Analysis from Foreign Language to Source Language-English to German, ERIC Document Reproduction Service No. ED109887.

Wongsothorn, A. (1983): Analysis of Language Transfers from Thai to English in Three Types of Discourse: Explanatory, descriptive, and persuasive, ERIC Document Reproduction Service No. ED 347820.

Woolmann, A. (1982): “Anatomy of a Translation,” Die Neueren Sprachen 81-4, pp. 385-406. 